\title{
PEMBATASAN TRANSAKSI TUNAI DI INDONESIA DALAM TINDAK PIDANA PENCUCIAN UANG
}

\author{
Oleh: \\ Agus Cakra Nugraha ${ }^{1}$
}

\begin{abstract}
Combating crime is repressive, in the old paradigm insists on Follow the Suspect is more focused on the pursuit of the perpetrators. Unlike the case with the new paradigm that emphasizes the pursuit of money or the Follow the Money or trying to trace property derived from crime, which is then reconstructed where wealth and what criminal act that gave birth to such property. This approach is easier than with conventional approaches for money laundering is the weakest link of a crime. Pursuing the perpetrators of crimes are relatively more difficult, than the pursuit of crime.
\end{abstract}

Keywords: Repressive crime, Chase the perpetrators, Track property, Money laundering

\begin{abstract}
Abstrak
Pemberantasan kejahatan secara represif, dalam paradigma lama menekankan pada Follow the Suspect lebih menitikberatkan pada pengejaran para pelaku kejahatan. Berbeda halnya dengan paradigma baru yang lebih menekankan untuk mengejar uang atau Follow the Money atau berupaya melacak harta kekayaan yang berasal dari kejahatan, yang kemudian direkonstruksi dari mana kekayaan itu dan tindak pidana apa yang melahirkan kekayaan tersebut. Pendekatan ini lebih mudah dibandingkan dengan pendekatan konvensional karena pencucian uang adalah mata rantai paling lemah dari suatu kejahatan. Mengejar pelaku kejahatan relatif lebih sulit, dibandingkan dengan mengejar hasil kejahatan.
\end{abstract}

Kata kunci: Kejahatan secara represif, Pengejaran para pelaku kejahatan, Melacak harta kekayaan, Pencucian uang

\section{PENDAHULUAN}

Dalam dasa warsa terakhir, permasalahan tindak pidana Pencucian Uang sudah berkembang dengan berbagai aspek permasalahan yang semakin kompleks. Kemajuan teknologi informasi telah berdampak pula terhadap tindak pidana pencucian uang yang tidak lagi terbatas dalam suatu wilayah negara tertentu, tetapi melintasi batas-batas yurisdiksi, dan menggunakan modus yang semakin bervariatif, memanfaatkan lembaga di luar sistemkeuangan. Sektor perbankan merupakan salah satu modus yang paling banyak dimanfaatkan oleh pelaku tindak pidana pencucian uang. Hal ini tentunya tidak dapat dilepaskan dengan perkembangan serta kemajuan ilmu pengetahuan dan teknologi

1 Hakim Pada Pengadilan Negeri Bangli, Bali, email: ck.nugraha@gmail.com 
khususnya di bidang komunikasi yang berdampak pula pada terintegerasinya sistem keuangan termasuk sistem perbankan yang menawarkan mekanisme lalu lintas dana antar negara yang dapat dilakukan dalam waktu yang sangat singkat.

Terdapat beberapa pengertian mengenai pencucian uang (money laundering). Secara umum, pengertian atau definisi tersebut tidak jauh berbeda satu sama lain. Black's Law Dictionary memberikan pengertian pencucian uang sebagai term used to describe investment or other transfer of money flowing from racketeeting, drug transaction, and other illegal sources into legitimate channels so that is original source cannot be traced (pencucian uang adalah istilah untuk menggambarkan investasi di bidangbidang yang legal melalui jalur yang sah, sehingga uang tersebut tidak dapat diketahui lagi asal usulnya). ${ }^{2}$ Pencucian uang adalah proses menghapus jejak asal uang hasil kegiatan illegal atau kejahatan melalui serangkaian kegiatan investasi atau transfer yang dilakukan berkali-kali dengan tujuan untuk mendapatkan status legal untuk uang yang di investasikan atau dimasukkan ke dalam sistem keuangan.

Secara langsung pencucian uang tidak merugikan orang tertentu atau perusahaan tertentu. Tampaknya secara sepintas lalu pencucian uang tidak ada korbannya. Billy Steel

2 Henry Campbell Black, 1990, Black's Law Dictionary Sixth Edition, St. Paul Minn. West Publishing Co., hlm. 884 pernah mengemukakan bahwa money laundering; "It Seem to be a victimless crime". Tetapi dibalik semua itu, dalam skala mikro sebenarnya pencucian uang berdampak pada lembaga penyediaan jasa keuangan, karena lembaga penyedia jasa keuangan tersebut dapat terjerumus ke dalam bahaya likuiditas dan kelangsungan hidup bisnisnya. Sementara dalam skala makro pencucian uang dapat menciptakan instabilitas sistem keuangan, distorsi ekonomi kemungkinan terganggunya kontrol jumlah uang yang beredar, dan dapat menyebabkan turunnya stabilitas pemerintahan.

Semakin meningkatnya trend transaksi tunai diduga antara lain dengan maksud untuk memutus pentrasiran atau pelacakan asal-usul sumber dana dan memutus pelacakan aliran dana kepada pihak penerima dana (beneficiary) yang pada akhirnya akan mengamputasi tugas PPATK dalam melakukan analisis transaksi keuangan mencurigakan.

Modus Transaksi tunai yang diduga untuk memutus pelacakan transaksi keuangan antara lain:

1. Setoran tunai dalam jumlah besar dari bukan nasabah suatu bank (walk in customer) untuk pihak ketiga yang merupakan nasabah di suatu bank berbeda.

2. Setoran tunai dalam jumlah besar dari pihak penyetor untuk pihak ketiga dimana baik pihak penyetor maupun penerima setoran merupakan nasabah di bank yang sama. 
3. Transaksi tarik tunai dalam jumlahbesaruntuktujuantertentu yang sebenarnya dapat dilakukan secara pemindahbukuan atau transfer dana, misalnya untuk pembayaran pembelian properti, kendaraan bermotor.

4. Transaksi Tunai dilakukan oleh penerima suap dengan menggunakan kartu ATM milik penyuap.

Pencucian uang (money laundering) di Indonesia disinyalir banyak berasal dari hasil tindak pidana korupsi, di samping tindak pidana lain. Anatomi korupsi menunjukkan bahwa, uang hasil korupsi merupakan derivative yang sangat penting bagi kelanjutan korupsi dan kejahatan lain sebagai transnasional crime. Korupsi masa kini bukan hanya untuk memenuhi hidup sehari-hari (pettycorruption) akan tetapi juga lebih sering menampilkan keserakahan yang luar biasa (grand-corruption) dari suatu rezim yang sedang berkuasa sebagaimana kita saksikan kejatuhan suatu rezim pemerintahan selalu dilatarbelakangi oleh korupsi.

Bertolak dari latar belakang permasalahan sebagaimana paparan di atas, maka rumusan masalah dalam penelitian ini adalah sebagai berikut :

1. Bagaimanakah pengaturan pembatasan transaksi tunai dalam tindak pidana pencucian uang di Indonesia?

2. Bagaimanakah pengaturan transaksi tunai dalam kebijakan kriminalisasi pencucian uang?
Penelitian ini merupakan karya ilmiah asli yang belum pernah diteliti sebelumnya. Adapun karya ilmiah yang terkait dengan karya ilmiah Penulis yaitu dengan judul Pertanggungjawaban Pidana Korporasi Dalam Tindak Pidana Pencucian Uang (Money Laundering) Di Indonesia yaitu karya ilmiah dari Ni Putu Ayu Leni Cahyarani tahun 2015 yang rumusan masalahnya adalah; 1 . Apakah hukum positif di Indonesia mengatur pertanggungjawaban tindak pidana yang dilakukan oleh korporasi dalam tindak pidana pencucian uang?; 2. Bagaimanakah pengaturan tindak pidana pencucian uang yang dilakukan oleh korporasi dimasa mendatang?3. Karya ilmiah lainnya yang terkait yaitu I Komang Kusyadi tahun 2015 dengan judul Fungsi Perbankan Dalam Upaya Membantu Tugas Pusat Pelaporan Dan Analisa Transaksi Keuangan (PPATK) Mencegah Terjadinya Tindak Pidana Pencucian Uang yang rumusan masalahnya adalah; 1. Bagaimana fungsi perbankan di bali dalam mencegah tindak pidana pencucian uang ?; 2. Apakah hambatan-hambatan dalam pencegahan pencucian uang ?4.

3 Ayu Leni Cahyarani, Ni Putu; RAI SETIABUDHI, I Ketut; TJATRAYASA, I Made. PERTANGGUNGJAWABAN PIDANA KORPORASI DALAM TINDAK PIDANA PENCUCIAN UANG (MONEY LAUNDERING) DI INDONESIA.Kertha Wicara, vol. 4 no. 1 edisi pebruari 2015. Available at: <https:// ojs.unud.ac.id/index.php/kerthawicara/article/ view/12005>. Diakses tanggal 3 Juli 2017.

4 Kusyadi, I Komang; RAI SETIABUDHI, I Ketut; SURYA DARMAJAYA, 
Jelas nampak perbedaan dari karya ilmiah tersebut dengan karya ilmiah yang dibuat oleh Penulis. Adapun keunggulan karya ilmiah ini dari karya ilmiah lainnya yaitu membahas lebih dalam tentang pengaturan pembatasan transaksi tunai dalam tindak pidana pencucian uang di Indonesia dan membahas lebih dalam tentang pengaturan transaksi tunai dalam kebijakan kriminalisasi pencucian uang.

Tujuan umum penelitian ini adalah untuk mendeskripsi serta menelaah asas maupun teori yang berhubungan dengan permasalahan yang bertalian dengan pembatasan transaksi tunai dalam tindak pidana pencucian uang di Indonesia. Tujuan khusus penelitian ini berhubungan paradigma science is product, dan berhubungan eratdengan permasalahan penelitian, sehingga tujuan khusus penelitian ini dapat dirumuskan sebagai berikut :

1. Untuk mendeskripsi serta menganalisis secara mendalam pengaturan pembatasan transaksi tunai dalam perbuatan tindak pidana pencucian uang di indonesia;

Ida Bagus. FUNGSI PERBANKAN DALAM UPAYA MEMBANTU TUGAS PUSAT PELAPORAN DAN ANALISA TRANSAKSI KEUANGAN (PPATK) MENCEGAH TERJADINYA TINDAK PIDANA PENCUCIAN UANG. Kertha Wicara, vol. 3 no. 3 edisi Juli 2014. <https://ojs.unud.ac.id/index.php/ kerthawicara/article.view/9555>. Diakses tanggal 3 Juli 2017.
2. Untuk mendeskripsi serta menganalisis secara mendalam pengaturan transaksi tunai dalam kebijakan kriminalisasi pencucian uang;

\section{METODE PENELITIAN}

Dalam setiap penelitian hendaknya memerlukan suatu metode agar suatu penelitian tersebut dapat dipertanggungjawabkan di kemudian hari sebagaimana mestinya. Dimana jenis penelitian yang digunakan penulis untuk pembuatan jurnal ini, menggunakan jenis penelitian hukum normatif. Menurut Abdulkadir Muhammad penelitian hukum normatif ialah penelitian hukum yang dilandasi oleh hukum yang tertulis dari berbagai aspek, yaitu aspek teori, sejarah, filosofi, perbandingan, struktur dan komposisi, ruang lingkup dan materi, konsistensi, penjelasan umum dan pasal dari pasal, formalitas dan mengikatnya, tetapi tidak mendasari aspek terapan atas implementasinya, maka penelitian hukum normatif sering juga disebut " penelitian hukum dogmatik" atau penelitian hukum teoritis (dogmatic or theoretical law research $)^{5}$

Dalam penelitian ini jenis pendekatan terhadap permasalahan dalam penelitian ini akan dilakukan dengan 4 (empat) cara pendekatan, yaitu pendekatan perundang-undangan

5 Abdulkadir Muhamad, 2004, Hukum dan Penelitian Hukum, Bandung: Citra Aditya Bakti, hlm. 101 
(statue approach), pendekatan analisis konsep hukum (analytical and conceptual approach), dan pendekatan perbandingan hukum (comparative approach). Dalam pendekatan perundang-undangan dilakukan pendekatan pada UU 8 Tahun 2010 tentang pencegahan dan pemberantasan tindak pidana pencucian uang, PPATK berkewajiban untuk melakukan analisis terhadap aliran uang yang mencurigakan karena sektor perbankan merupakan salah satu modus yang paling banyak dimanfaatkan oleh pelaku tindak pidana pencucian uang. ${ }^{6}$ Pendekatan analisis konsep hukum ini dilakukan untuk menganalisis teori-teori hukum maupun konsep hukum yang berkaitan dengan penelitian terhadap pembatasan transaksi tunai dalam tindak pidana pencucian uang di Indonesia, serta pendekatan perbandingan hukum ini mengacu pada perbandingan UU 8 Tahun 2010 terhadap undang-undang yang ada kaitannya terhadap pencucian uang agar kita mengetahui apakah di dalam undang-undang tersebut adanya norma kosong dan kekaburan norma.

\section{HASIL DAN PEMBAHASAN}

\subsection{Pembatasan Transaksi}

Tunai Dalam Tindak Pidana Pencucian Uang Di Indonesia

KetentuanyangadadalamUUNo. 8 Tahun 2010 terkait perumusan tindak pidana pencucian uang menggunakan

6 Undang-undang Nomor 8 Tahun 2010 tentang Pencegahan dan Pemberantasan Tindak Pidana Pencucian Uang. kata setiap orang dimana dalam pasal 1 angka (9) ditegaskan bahwa Setiap orang adalah orang perseorangan atau korporasi. Sementara pengertian korporasi terdapat dalam pasal 1 angka (10). Dalam pasal ini disebutkan bahwa Korporasi adalah kumpulan orang dan/atau kekayaan yang terorganisasi baik merupakan badan hukum maupun bukan badan hukum. Sementara itu, yang dimaksud dengan transaksi menurut ketentuan dalam Undang-undang ini adalah seluruh kegiatan yang menimbulkan hak atau kewajiban atau menyebabkan timbulnya hubungan hukum antara dua pihak atau lebih. Adapun "transaksi keuangan" diartikan sebagai transaksi untuk melakukan atau menerima penempatan, penyetoran, penarikan, pemindah bukuan, pentransferan, pembayaran, hibah, sumbangan, penitipan, dan atau kegiatan lain yang berhubungan dengan uang. Transaksi keuangan yang menjadi unsur tindak pidana pencucian uang adalah transaksi keuangan yang mencurigakan atau patut dicurigai baik transaksi dalam bentuk tunai maupun melalui proses pentransferan/memindah buku kan.

Secara garis besar unsur pencucian uang terdiri dari: unsur objektif(actus reus) dan unsur subjektif (mens rea). Unsur objektif (actus reus) dapat dilihat dengan adanya kegiatan menempatkan, mentransfer, membayarkan atau membelanjakan, menghibahkan atau menyumbangkan, menitipkan, membawa keluar negeri, 
menukarkan atau perbuatan lain atas harta kekayaan (yang diketahui atau patut diduga berasal dari kejahatan). Sedangkan unsur subjektif (mens rea)dilihat dari perbuatan seseorang yang dengan sengaja, mengetahui atau patut menduga bahwa harta kekayaan berasal dari hasil kejahatan, dengan maksud untuk menyembunyikan atau menyamarkan harta tersebut. ${ }^{7}$

Tindak pidana pencucian uang salah satunya harus memenuhi unsur adanya perbuatan melawan hukum sebagaimana dimaksud dalam pasal 3 UU No. 8 Tahun 2010, dimana perbuatan melawan hukum tersebut terjadi karena pelaku melakukan tindakan pengelolaan atas harta kekayaan yang merupakan hasil tindak pidana. Pengertian hasil tindak pidana diuraikan pada Pasal 2 UU No. 8 Tahun 2010. Pada pasal ini Harta kekayaan yang dikualifikasikan sebagai harta kekayaan hasil tindak pidana adalah harta yang berasal dari kejahatan seperti: korupsi, penyuapan, narkotika, psikotropika, penyelundupan tenaga kerja, penyelundupan migrant, bidang perbankan, bidang pasar modal, bidang asuransi, kepabeanan, cukai, perdagangan orang, perdagangan senjata gelap, terorisme, penculikan, pencurian, penggelapan, penipuan, pemalsuan uang, perjudian, prostitusi, bidang perpajakan, bidang lingkungan hidup, bidang kehutanan, bidang

7 Supiadi, 2012, Tindak Pidana Pencucian Uang, diakses pada situs: http://www. negarahukum.com/hukum/1562.html, diakses tanggal 3 Januari 2014. kelautan dan perikanan serta tindak pidana lain yang diancam hukuman 4 tahun penjara.

Dalam melakukan pencucian
uang pelaku tidak terlalu mempertimbangkan hasil yang akan diperoleh, dan besarnya biaya yang harus dikeluarkan. Karena, tujuan utamanya adalah untuk menyamarkan atau menghilangkan asal-usul uang sehingga hasil akhirnya dapat dinikmati atau digunakan secara aman.

Jika bank menemukan adanya suatu transaksi yang mencurigakan, bank dapat melaporkan kepada BI. Namun, apabila terdapat adanya transaksi yang mencurigakan tersebut, tidak serta merta menunjukkan telah terjadi tindak pidana pencucian uang, akan tetapi harus diteliti terlebih dulu. Peraturan Bank Indonesia tersebut, bukan berarti menjadi tidak berlaku setelah berlakunya undang-undang Tindak Pidana Pencucian Uang. Peraturan tersebut tetap berlaku sebagai sarana yang dapat membantu secara operasional undang-undang Tindak Pidana Pencucian Uang, karena ruang lingkup money laundering sifatnya luas bukan hanya perbankan melainkan juga non bank.

Sehubungan dengan telah berlakunya Undang-Undang No. 15 Tahun 2002 yang merupakan dasar hukum untuk melakukan penanggulangan terhadap Tindak Pidana Pencucian Uang, maka dalam Pasal 2 undang-undang ini ditentukan, beberapa hasil kejahatan 
yang jumlahnya lima ratus juta rupiah atau lebih atau nilai yang setara, yang diperoleh baik langsung maupun tidak langsung dari tindak pidana korupsi, penyuapan, penyelundupan barang, penyelundupan tenaga kerja, penyelundupan imigran, perbankan, perdagangan gelap narkotika dan psikotropika, perdagangan budak, wanita dan anak, perdagangan senjata gelap, penculikan, terorisme, pencurian, penggelapan, dan penipuan merupakan tindak pidana yang dapat diancam dan dijatuhi pidana. Namun, apabila memperhatikan batasan uang ilegal sebesar Rp 500 juta rupiah yang tergolong terlalu tinggi apabila dibandingkan dengan Amerika Serikat (US\$ 10.000), Australia (AUS\$ 10.000), menurut Yunus Husein, ${ }^{8}$ Deputi Direktur Direktorat Hukum Bank Indonesia, dengan batasan sebesar itu dikhawatirkan banyak uang hasil kejahatan yang jumlahnya di bawah batasan tersebut lolos dari jangkauan Undang-Undang No. 15 Tahun 2002. Kekhawatiran tersebut tampaknya terbukti, yaitu sebagaimana yang dinyatakan oleh Direktur Unit Khusus Investasi Perbankan Bank Indonesia (UKIP), bahwa kendala yang sering ditemui UKIP dan PPATK saat menyerahkan laporan ke penyidik adalah masih adanya beda persepsi di

8 Yunus Husein, Pusat Pelaporan dan Analisis Transaksi Keuangan (PPATK), Sebuah Lembaga Yang Dibentuk Dengan Undang-Undang No. 15 Tahun 2002, diakses pada situs: http://id.wikipedia. org/wiki/Yunus_Husein, diakses tanggal 3 Desember $20 \overline{13}$. antara kedua belah pihak. Penyidik sering menolak untuk menindak lanjuti laporan transaksi mencurigakan dari UKIP dan PPATK dengan alasan tidak ada indikasi korupsi karena nilai transaksinya di bawah RP 500 juta. $^{9}$

\subsection{Transaksi Tunai Dalam Kebijakan Kriminalisasi Pencucian Uang}

Upaya pencegahan dan pemberantasantindakpidanaPencucian Uang memerlukan landasan hukum yang kuat untuk menjamin kepastian hukum, efektivitas penegakan hukum serta penelusuran dan pengembalian Harta Kekayaan hasil tindak pidana. ${ }^{10}$ Penelusuran Harta Kekayaan hasil tindak pidana pada umumnya dilakukan oleh lembaga keuangan melalui mekanisme yang diatur dalam peraturan perundang-undangan. Lembaga keuangan memiliki peranan penting khususnya dalam menerapkan prinsip mengenali Pengguna Jasa dan melaporkan Transaksi tertentu kepada otoritas (financial intelligence unit) sebagai bahan analisis dan untuk selanjutnya disampaikan kepada penyidik. Lembaga keuangan tidak hanya berperan dalam membantu penegakan hukum, tetapi juga menjaga dirinya dari berbagai risiko, yaitu risiko operasional, hukum, terkonsentrasinya

9 Hukumonline.com, PPATK Tertibkan Peraturan Pelaksanaan UU Pencucian Uang, diakses tanggal 3 Deseember 2013.

10 Guy Stessens, 1984, Money Laundering A New International Law Enforcement Model, (Cambridge: University Press, 2000), hlm. 184. 
Transaksi, dan reputasi karena tidak lagi digunakan sebagai sarana dan sasaran oleh pelaku tindak pidana untuk mencuci uang hasil tindak pidana. Dengan pengelolaan risiko yang baik, lembaga keuangan akan mampu melaksanakan fungsinya secara optimal sehingga pada gilirannya sistem keuangan menjadi lebih stabil dan terpercaya. ${ }^{11}$ Upaya yang dilakukan tersebut dirasakan belum optimal, antara lain karena peraturan perundang-undangan yang ada ternyata masih memberikan ruang timbulnya penafsiran yang berbedabeda, adanya celah hukum, kurang tepatnya pemberian sanksi, belum dimanfaatkannya pergeseran beban pembuktian, keterbatasan akses informasi, sempitnya cakupan pelapor dan jenis laporannya, serta kurang jelasnya tugas dan kewenangan dari para pelaksana Undang-Undang tersebut di atas.

Kebijakan kriminalisasi pada masa yang akan datang perlu memperhatikan hal-hal sebagai berikut:

a. Masalah Percobaan, Pembantuan dan Permufakatan Jahat.

Karena aturan pemidanaan mengenai percobaan, pembuatan dan permufakatan jahat tidak disebutkan sebagai ketentuan umum. Artinya, pasal 3 ayat 1 itu hanya berlaku untuk tindak pidana dalam pasal 3 ayat

11 Edi Nasution, 2011, Memahami Praktik Pencucian Uang Hasil Kejahatan (Money Laundering), hlm. 17.
1 sehingga tidak jelas apakah ini berlaku pasal lain atau tidak. Hal ini penting karena ketentuan ini jelas berbeda dengan yang diatur dalam KUHP, maka perlunya formulasi yang lebih jelas dalam ketentuan umum.

b. Pidana Mininal Khusus

UU TPPU mencantumkan ancaman pidana minimal khusus, namun tidak memuat aturan/ pedoman penerapan pidananya secara khusus. Hal ini akan menimbulkan masalah, karena dilihat dari system pemidanaan, jumlah ancaman pidana (minimal maupun maksimal) hanya merupakan salah satu subsistem yang tidak dapat begitu saja diterapkan di dalam perumusan delik. Agar dapat diterapkan, harus disertai dengan sub-sistem mengenai aturan pemindanaan/pedoman penerapannya terlebih dahulu. Oleh karena itu formulasi yang akan datang harus disertai dengan pedoman penerapan.

c. Pertanggungjawaban Pidana Terhadap Korporasi

Penetapan subyek hukum korporasi sebagai pelaku tindak pidana pencucian masing mengandung beberapa kelemahan. Kelemahan tersebut menurut Barda antara lain perumusan pada pasal 4 ayat 1 , seolaholah korporasi baru dapat dipidana apabila tindak pidana dilakukan oleh pengurus dan/atau kuasa pengurus. Jadi kalau dilakukan oleh karyawan/ pegawai/ buruh/ orang lain bukan pengurus atau bukan kuasa 
pengurus, maka korporasi tidak dapat dipertanggungjawabkan. Di samping itu ancaman pidana denda untuk korporasi yang maksimumnya diperberat sepertiga tidak disertai dengan ketentuan khusus untuk pelaksanaan pidana denda yang tidak dibayar oleh korporasi.

\section{KESIMPULAN}

1. Upaya pencegahan dan pemberantasan tindak pidana Pencucian Uang memerlukan landasan hukum yang kuat untuk menjamin kepastian hukum, efektivitas penegakan hukum serta penelusuran dan pengembalian Harta Kekayaan hasil tindak pidana. Harta kekayaan yang berasal dari berbagai kejahatan atau tindak pidana tersebut pada umumnya tidak langsung dibelanjakan atau digunakan oleh para pelaku kejahatan karena apabila langsung digunakan akan mudah dilacak oleh penegak hukum mengenai sumber diperolehnya harta kekayaan tersebut, sehingga biasanya para pelaku kejahatan terlebih dahulu mengupayakan agar harta kekayaan yang diperoleh dari kejahatan tersebut masuk ke dalam sistem keuangan (financial system).

2. Dimana pendekatan follow the money dalam mengkriminalisasi pencucian uang, yaitu perbuatan menyembunyikan dan menyamarkan harta kekayaan hasil tindak pidana, sehingga seolah-olah tampak sebagai kekayaan yang sah. Dalam setiap tindak pidana, setidaknya ada tiga komponen, yaitu pelaku, tindak pidana yang dilakukan, dan hasil tindak pidana. Hasil tindak pidana dapat berupa uang atau harta kekayaan lain. Pendekatan follow the money mendahulukan mencari uang atau harta kekayaan hasil tindak pidana dibandingkan dengan mencari pelaku kejahatan.

\section{DAFTAR PUSTAKA}

\section{Buku:}

Abdulkadir Muhamad, 2004, Hukum dan Penelitian Hukum, Citra Aditya Bakti, Bandung.

Henry Campbell Black, 1990, Black's Law Dictionary Sixth Edition, St. Paul Minn. West Publishing Co.

Stessens Guy, 2000, Money Laundering A New International Law Enforcement Model, Cambridge: University Press.

\section{Jurnal:}

Ayu Leni Cahyarani, Ni Putu; RAI SETIABUDHI, I Ketut; TJATRAYASA, I Made. PERTANGGUNGJAWABAN PIDANA KORPORASI DALAM TINDAK PIDANA PENCUCIAN UANG (MONEY LAUNDERING) DI INDONESIA.Kertha Wicara, 
vol. 4 no. 1 edisi pebruari 2015. Available at: <https://ojs.unud. ac.id/index.php/kerthawicara/ article/view/12005>.Diakses tanggal 3 Juli 2017.

Edi Nasution, 2011, Memahami Praktik Pencucian Uang Hasil Kejahatan (Money Laundering).

Kusyadi, I Komang; RAI SETIABUDHI, I Ketut; SURYA DARMAJAYA， Ida Bagus. FUNGSI PERBANKAN DALAMUPAYAMEMBANTU TUGAS PUSAT PELAPORAN DAN ANALISA TRANSAKSI KEUANGAN (PPATK) MENCEGAH TERJADINYA TINDAK PIDANA PENCUCIAN UANG. Kertha Wicara, vol. 3 no. 3 edisi Juli 2014. <https://ojs.unud.ac.id/ index.php/kerthawicara/article/ view/9555>. Diakses tanggal 3 Juli 2017.

\section{Peraturan Perundang-undangan}

Undang-undang Nomor. 15 Tahun 2002 tentang Tindak Pidana Pencucian Uang.

Undang-undang Nomor. 25 Tahun 2003 tentang Tindak Pidana Pencucian Uang.

Undang-undang Nomor. 8 Tahun 2010 tentang Pencegahan dan Pemberantasan Tindak Pidana Pencucian Uang.

Undang-Undang No. 7 Tahun 1992 tentang Perbankan.
Undang-undang Nomor 10 Tahun 1998 tentang Perbankan.

\section{Internet:}

Supiadi,2012, TindakPidanaPencucian Uang, diakses pada situs: $<$ http://www.negarahukum. com/hukum/5162.html, diakses tanggal 3 Julii 2017.

Yunus Husein, Pusat Pelaporan dan Analisis Transaksi Keuangan (PPATK), Sebuah Lembaga Yang Dibentuk Dengan Undang-Undang No. 15 Tahun 2002, diakses pada situs: $<$ http:// id.PPATK.org/wiki/Yumus Husein, diakses tanggal 3 Juli 2017.

PPATK.com, PPATK Tertibkan Peraturan Pelaksanaan UU Pencucian Uang, diakses tanggal 3 juli 2017. 


\title{
PERLINDUNGAN KARYA CIPTA FOTO CITIZEN JOURNALIST YANG DIPUBLIKASIKAN DI INSTAGRAM
}

\author{
Oleh: \\ Ni Made Dwi Marini Putri ${ }^{1}$
}

\begin{abstract}
The development of the current paradigm demonstrate initiative of the citizens to share information in their possession to the public. Citizen who was only a reader, now turned into a citizen journalist, who sends the picture to the press on Instagram account on an event that attracts attention. In this research, there are two issues to be discussed namely 1) How is the protection of moral rights and economic rights over the photos produced by citizen journalist on Instagram? 2) How can the efforts of a citizen journalist to protect the copyrighted works uploaded on Instagram? This research is an empirical juridical study that examines the problem of copyright photography protection in Instagram. Moral rights protection of citizen journalist on Instagram photo is done with the mention of names of the photographer (citizen journalist) and copyright holder (press accounts on Instagram). Protection of economic rights of citizen journalism photo on Instagram as stipulated in the Act of the Republic of Indonesia Number 28 of 2014 on Copyright only applies to photographs with human objects. Efforts that can be done by a citizen journalist to protect copyrighted works uploaded on Instagram are preventive efforts, respresive efforts and pre-emtive efforts.
\end{abstract}

Keywords: protection, copyright, citizen journalist, moral rights, economic rights.

\begin{abstract}
Abstrak
Perkembangan paradigma di era informasi saat ini menunjukkan inisiatif dari warga untuk membagikan informasi yang dimilikinya kepada publik secara cepat dan up to date. Warga yang tadinya hanya seorang pembaca, kini cenderung menjadi citizen journalist yang cenderung berinisiatif dan aktif mengirimkan hasil fotonya kepada akun pers di Instagram mengenai suatu peristiwa yang menarik perhatian. Dalam penelitian ini terdapat dua permasalahan inti yaitu 1) Bagaimanakah perlindungan hak moral dan hak ekonomi atas foto yang dihasilkan oleh seorang citizen journalist di Instagram? 2) Bagaimanakah upaya-upaya yang dapat dilakukan seorang citizen journalist untuk melindungi karya cipta fotonya yang diunggah di Instagram? Penelitian ini merupakan penelitian yuridis empiris yang mengkaji mengenai masalah perlindungan karya cipta fotografi di Instagram. Perlindungan hak moral foto citizen journalist di Instagram dilakukan dengan penyebutan nama pencipta (citizen journalist) dan pemegang hak cipta (akun pers pada Instagram). Perlindungan hak ekonomi foto citizen journalist di Instagram sebagaimana yang diatur dalam Undang-undang Republik Indonesia Nomor 28 Tahun 2014 Tentang Hak Cipta hanya berlaku

1 Kementrian Hukum dan Hak Asasi Manusia Republik Indonesia Kantor Wilayah Bali., Email: dw1m4r1n1@gmail.com
\end{abstract}


pada karya foto dengan objek manusia. Upaya-upaya yang dapat dilakukan seorang citizen journalist untuk melindungi karya cipta fotonya yang diunggah di Instagram adalah upaya preventif, upaya respresif serta upaya pre-emtif.

\section{Kata kunci: perlindungan, karya cipta foto, citizen journalist, hak moral, hak ekonomi.}

\section{PENDAHULUAN}

Akselerasi informasi membutuhkan akses yang besar terhadap perolehan informasi itu sendiri. Akses yang besar hanya bisa didapat dari sumber berita yang banyak, cepat, tepat dan akurat. Perkembangan menunjukkan adanya peningkatan partisipasi masyarakat dalam mengumpulkan, melaporkan, menganalisis hingga menyampaikan informasi kepada masyarakat dengan dimengunggah foto suatu kejadian di media sosial. Salah satu media sosial yang sering dijadikan tempat menyampaikan informasi adalah Instagram. Instagram adalah aplikasi berbagi foto ciptaan Kevin Systrom and Mike Krieger, yang memungkinkan pengguna untuk berbagi foto dan video publik atau pada layanan para pengguna.

\section{Gambar 1 Foto karya Citizen Journalist}

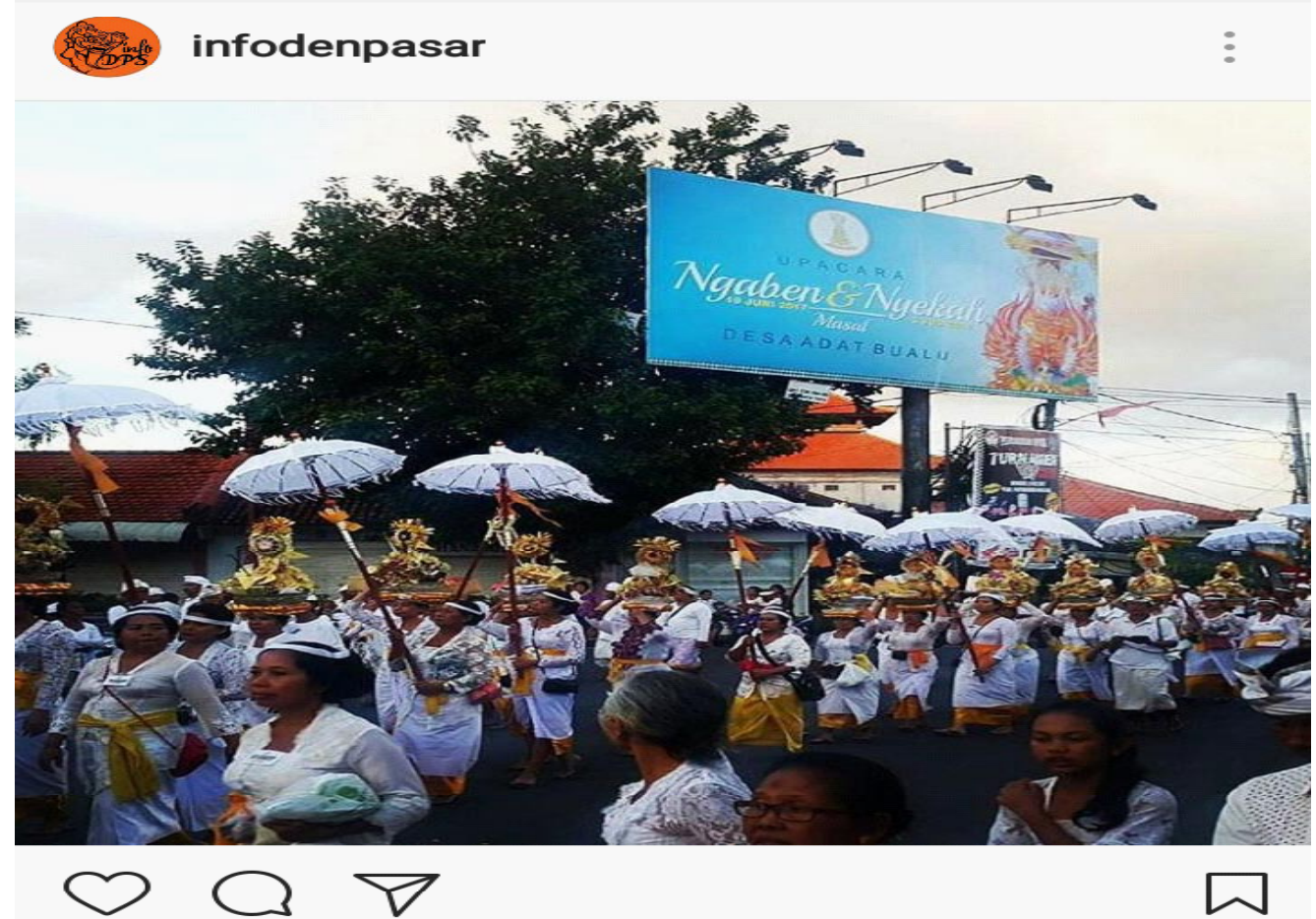

Liked by lulumaianksari and 4,781 others infodenpasar Nyekah massal desa adat Bualu menuju segara samuh melewati jalan Pratama Tanjung Benoa. Info dari @joel_kenji \#CitizenJournalist \#InfoDenpasar \#Balitoday

Sumber: http://www.instagram.com/p/BWEJYBdlr07/?taken-by=infodenpasar 


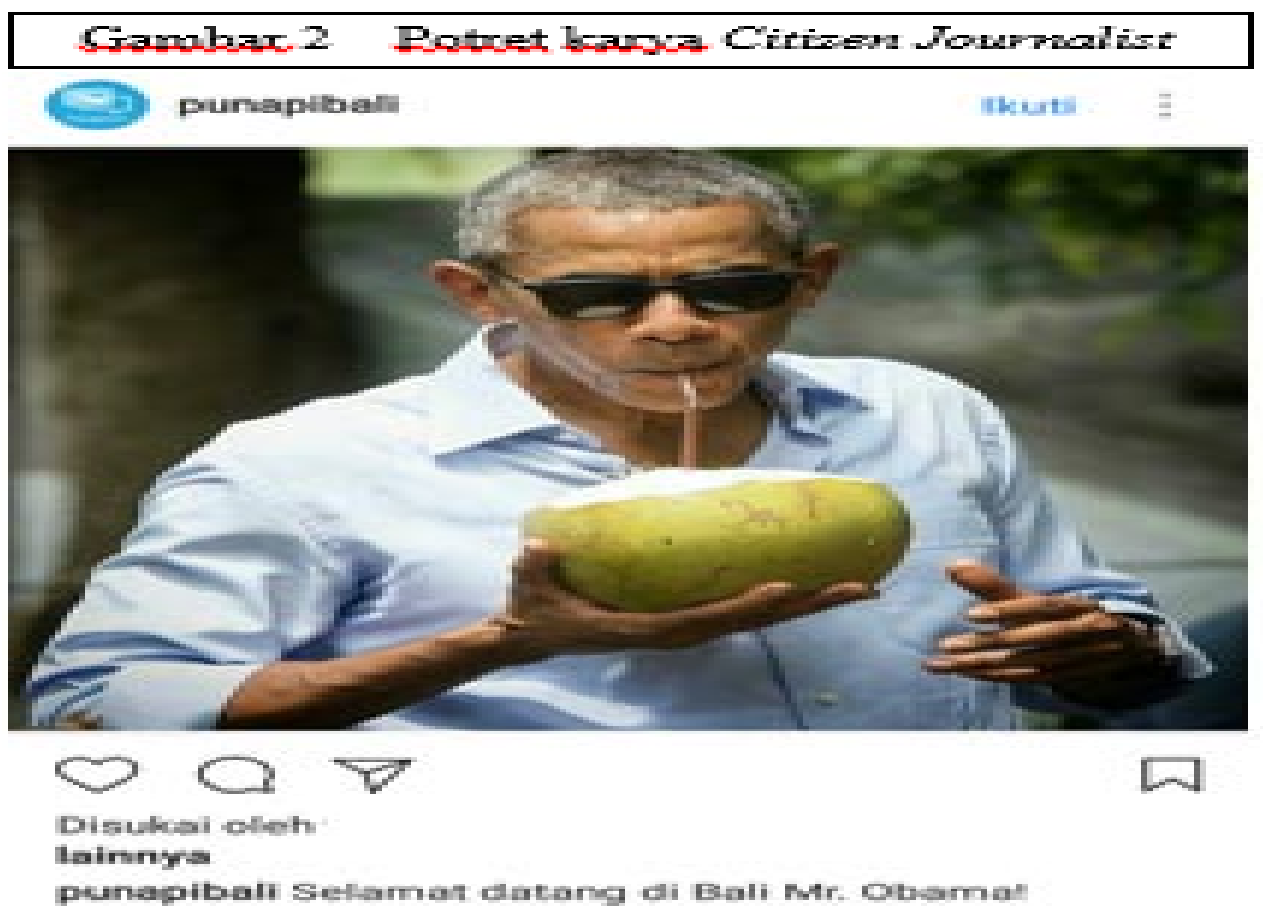

Dari intormat yang didapat, katomy Mt. Obarna dan koluarga Iagl molnap di sobualh hotal di dacrah Dutas Saymin Ubud itmo:

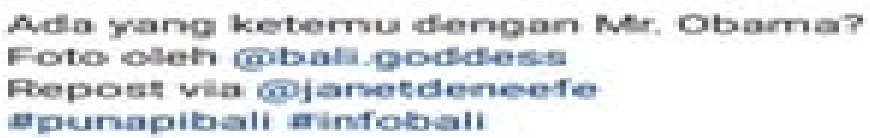

Sumber:https://www.instagram.com/p/BVrhJohj3MI/?taken-by=punapibali.

Instagram mulanya digunakan untuk berbagai foto dengan keluarga dan teman, namun dalam perkembangannya, Instagram digunakan untuk berbagi berita oleh para citizen journalist atau jurnalis warga. Citizen journalist yang secara kebetulan menemukan suatu peristiwa menarik dan ingin membaginya kepada orang lain akan mengambil foto dari peristiwa tersebut dan mengirimnya kepada akun Instagram yang menyajikan berita, seperti Info Denpasar, Lambe_Turah dan lain-lain. Media-media tersebut, selain memiliki jurnalis sendiri, juga mendapatkan berita dari citizen journalist. Mereka memberikan kesempatan bagi masyarakat yang ingin berbagi informasi kepada masyarakat melalui karya foto.

Hasil foto merupakan salah satu bentuk karya cipta yang dilindungi oleh Undang-undang Republik Indonesia Nomor 28 Tahun 2014 Tentang Hak Cipta. Dalam Pasal 40 ayat (1) huruf $\mathrm{k}$ dinyatakan Ciptaan yang dilindungi meliputi Ciptaan dalam bidang ilmu pengetahuan, seni, dan sastra, terdiri atas: karya fotografi. Dalam 
Penjelasan huruf k, yang dimaksud dengan "karya fotografi" meliputi semua foto yang dihasilkan dengan menggunakan kamera. Sebagai sebuah hak cipta, maka pencipta memiliki hak eksklusif yang terdiri dari hak ekonomi dan hak moral. Dalam penelitian ini akan dibahas mengenai perlindungan hak cipta foto citizen journalist yang dipublikasikan di Instagram.

Berdasarkan latar belakang yang telah diuraikan sebelumnya, maka dapat dirumuskan permasalahan sebagai berikut:

a. Bagaimanakah perlindungan hak moral dan hak ekonomi atas foto yang dihasilkan oleh citizen journalist di Instagram?

b. Bagaimanakah upaya-upaya yang dapat dilakukan seorang citizen journalist untuk melindungi karya cipta fotonya yang diunggah di Instagram?

Orisinalitas penelitian mengenai perlindungan hak cipta foto citizen journalist yang dipublikasikan di Instagram dilakukan dengan membandingkan beberapa penelitian lain, diantaranya:

1. "Efektivitas Pengaturan Hukum Hak Cipta Dalam Melindungi Karya Seni Tradisional Daerah" yang ditulis oleh Emma Valentina Teresha Senewe. Dalam penelitian tersebut, ada dua hasil temuan yakni di Indonesia, terdapat peraturan perundang-undangan yang mengatur tentang karya seni tradisional daerah. Ketentuan hukum mengenai karya seni tradisional daerah tersebut terdapat dalam Undang-undang Nomor 28 Tahun 2014 tentang Hak Cipta. Pengkajian mengenai pengaturan karya seni tradisional daerah dalam undang-undang tersebut menghasilkan temuan berupa beberapa kelemahan dan kelebihan. Pengaturan mengenai perlindungan karya seni tradisional daerah tersebut tertuang dalam Pasal 10 dimana pengaturan tersebut masih terlalu umum. Hal ini mengakibatkan banyaknya pelanggaran hak cipta terhadap karya seni tradisional daerah dan minimnya upaya pemerintah dalam menanggulangi pelanggaran hak cipta tersebut. Penemuan tersebut diharapkan dapat menjadi bahan kajian untuk perbaikan pada peraturan perundang-undangan selanjutnya. $^{2}$ Dalam penelitian perlindunganhakciptafotocitizen journalist yang dipublikasikan di Instagram, ruang lingkup hak cipta yang dibahas adalah karya foto sedangkan dalam penelitian yang ditulis olehEmma Valentina Teresha Senewe berada pada ruang lingkup karya seni.

2. "Perlindungan Hak Cipta Atas

2 Emma Valentina Teresha Senewe, 2015, Efektivitas Pengaturan Hukum Hak Cipta Dalam Melindungi Karya Seni Tradisional Daerah, Jurnal LPPM Bidang EkoSosBudKum Volume 2 Nomor 2 Tahun 2015 Edisi Oktober, Manado, hlm.1. 
Buku” sebagaimana yang ditulis oleh Denny Kusmawan. Dalam penelitian ini dibahas mengenai buku sebagai salah satu objek hak cipta, oleh sebab itu, karya buku mendapatkan perlindungan hak cipta atas segala bentuk pelanggaran. Pelanggaran hak cipta atas buku justru banyak dilakukan di lingkungan kampus dimana dosen dan mahasiswa yangmenggandakanbukudengan cara fotocopy dan pengutipan yang tidak mencatumkan sumber rujukan. Rekomendasi darri penelitian ini adalah dengan mengatur mengenai jumlah halaman atau persentase buku yang boleh digandakan dalam undang-undang serta melakukan kampanye antiplagiasi. ${ }^{3}$ Dalam penelitian perlindungan hak cipta foto citizen journalist yang dipublikasikan di Instagram, pembahasan mengacu pada karya-karya foto yang dihasilkan oleh citizen journalist dan dipublikasika pada Instagram.

3. "Perlindungan Hak Moral dalam Hukum Hak Cipta", yang ditulis oleh Yuliana Diah Warsiki Susi Irianti. Dalam penelitian tersebut dibahas mengenai perlindungan hak moral yang melekat pada setiap ciptaan. Dalam penelitian tersebut, penulis menguraikan

3 Denny Kusmawan, 2014, Perlindungan Hak Cipta Atas Buku, Jurnal Perspektif Volume XIX No. 2 Tahun 2014 Edisi Mei, Surabaya, hlm.137. mengenai esensi right of paternity atau right of integrity sebagai dasar untuk menentukan adanya pelanggaran hak cipta. Perlindungan hak moral dilakukandenganmencantumkan nama pencipta dari sebuah karya cipta dan tidak mengubah hasil ciptaan yang bertendensi merugikan pencipta. ${ }^{4}$ Dalam penelitian tersebut membahasn mengenai hak moral yang dapat berkontribusi dalam kajian mengenai perlindungan hak moral foto citizen journalist di Instagram.

Tujuan penelitian dalam jurnal ilmiah ini terdiri dari tujuan umum dan tujuan khusus. Tujuan umum dalam penelitian ini adalah untuk menganalisis perlindungan hak cipta foto citizen journalist yang dipublikasikan di Instagram. Tujuan khusus dalam penelitian ini adalah untuk menganalisis perlindungan hak moral dan hak ekonomi atas foto yang dihasilkan oleh citizen journalist di Instagram dan untuk menemukan upaya-upaya yang dapat dilakukan seorang citizen journalist untuk melindungi karya cipta fotonya yang diunggah di Instagram.

\section{METODE PENELITIAN}

Penelitian ini menggunakan pendekatan yuridis empiris yakni

4 Yuliana Diah Warsiki Susi Irianti, 2014, Perlindungan Hak Moral Dalam Hukum Hak Cipta, Jurnal Hukum dan Masyarakat Volume XIII, Nomor 3, Kupang, hlm.26. 
mengkaji mengenai masalah perlindungan hak cipta atas karya fotografi. Perlindungan karya cipta fotografi ini dipertegas pada Pasal 40 ayat (1) yang menyatakan bahwa karya fotografi merupakan ciptaan yang dilindungi. Dalam Penjelasan Pasal 40 huruf $\mathrm{k}$ ditegaskan bahwa karya fotografi mencakup semua foto yang dihasilkan dari tangkapan kamera. Penelitian ini bersifat deskriptif dengan menjabarkan mengenai implementasi perlindungan hukum terhadap karya cipta dalam bentuk fotografi yang dihasilkan oleh citizen journalist.

Data yang digunakan dalam penelitian ini adalah data primer dan data sekunder. Data primer berasal dari hasil pengamatan yang dilakukan secara tidak langsung, yakni melalui aplikasi Instagram. Data sekunder terdiri dari bahan hukum primer dan bahan hukum sekunder. Bahan hukum berasal dari bahan hukum primer yakni Undang-undang Republik Indonesia Nomor 28 Tahun 2014 Tentang Hak Cipta dan Undang-undang Nomor 40 Tahun 1999 tentang Pers. Bahan hukum sekunder yang digunakan adalah literatur mengenai hak cipta, hukum penyiaran dan hukum media.

Pengumpulan bahan hukum dilakukan dengan teknik studi kepustakaan. Melalui teknik studi kepustakaan ini, bahan hukum dikumpulkan, dicatat dan digunakan dalam penelitian dengan mencatumkan sumber rujukan yang jelas untuk menghindari plagiasi. Analisis bahan hukum dilakukan secara kualitatif yakni dengan menguraikan perlindungan hak cipta foto citizen journalist yang dipublikasikan di Instagram. Penjabaran disampaikan secara deskriptif analitis.

III HASIL DAN PEMBAHASAN 3.1. Perlindungan Hak Moral dan Hak Ekonomi Atas Foto Yang Dihasilkan oleh Citizen Journalist di Instagram

Kehadiran citizen journalist dalam media massa saat ini, menunjukkan adanya suatu pergeseran paradigma dimana para pembaca kini telah bermigrasi menjadi seorang jurnalis. Para pembaca memiliki kepedulian untuk membagikan informasi kepada orang lain melalui media yang dapat dibaca oleh banyak orang. Warga telah melakukan berbagai kegiatan pers ${ }^{5}$ dan diunggah secara online untuk disebarluaskan. Instagram adalah salah satu aplikasi yang digunakan oleh para pembaca untuk membagi foto yang memuat suatu informasi, misalnya mengenai kebakaran, kemacetan lalu lintas, upacara keagamaan, fenomena sosial masyarakat dan sebagainya.

\footnotetext{
5 Menurut Pasal 1 angka 1 Undang-undang Nomor 40 Tahun 1999 tentang Pers, pers adalah lembaga sosial dan wahana komunikasi massa yang melaksanakan kegiatan jurnalistik meliputi mencari, memperoleh, memiliki, menyimpan, mengolah, dan menyampaikan informasi baik dalam bentuk tulisan, suara, gambar, suara dan gambar, serta data dan grafik maupun dalam bentuk lainnya dengan menggunakan media cetak, media elektronik, dan segala jenis saluran yang tersedia.
} 
Foto adalah sebuah karya cipta yang menggabungkan unsur seni, keilmuan (science), aplikasi dan kemampuan untuk menangkap sebuah moment dan mengabadikannya dalam sebuah karya cipta. Foto merupakan suatu benda, baik dalam bentuk softcopy maupun hardcopy yang dihasilkan dari tangkapan kamera sebagaimana yang ditegaskan dalam Penjelasan Pasal 40 ayat (1) huruf k. Sejalan dengan klasifikasi mengenai macam-macam benda, maka sebagai sebuah karya cipta, hak cipta termasuk sebagai benda bergerak yang tidak bertubuh. ${ }^{6}$ Benda bergerak ini tentu saja memiliki nilai ekonomi dan melahirkan hak moral yang harus dilindungi. Perlindungan terhadap hak ekonomi dan hak moral tersebut merupakan pengejawantahan dari reward theory sebagaimana yang dikemukakan oleh Robert M Sherwood. Teori ini pada intinya memberikan penghargaan atas upaya-upaya kreatifnya dalam menemukan atau menciptakan karyakarya intelektual. Penghargaan tersebut tidak lepas dari perwujudan pengakuan terhadap karya intelektual yang telah dihasilkannya. ${ }^{7}$

Foto yang dihasilkan oleh citizen journalist merupakan suatu karya cipta yang mendapatkan perlindungan hak

6 Gatot Supramono, 2010, Hak Cipta dan AspekAspek Hukumnya, Rineka Cipta, Jakarta, hlm.29

7 Ni Ketut Supasti Dharmawan, 2011, Hak Kekayaan Intelektual dan Harmonisasi Hukum Global Rekonstruksi Pemikiran Terhadap Perlindungan Program Komputer, Badan Penerbit Universitas Diponegoro, Semarang, hlm.49 cipta, yakni hak eksklusif yang terdiri dari hak moral dan hak ekonomi. Ketentuan mengenai hak cipta ini tidak lepas dari tuntutan globalisasi ekonomi yang menginginkan terbentuknya sistem organisasi dan komunikasi antar masyarakat di seluruh dunia. Hal ini dilakukan dengan mengikuti sistem dan kaidah-kaidah yang sama." Kondisi tersebut menginginkan adanya harmonisasi ketentuan mengenai perlindungan hak cipta. Secara internasional, perlindungan hak cipta meliputi hak moral dan hak ekonomi. Kedua hak tersebut juga diakomodir dalam Undang-undang Republik Indonesia Nomor 28 Tahun 2014 Tentang Hak Cipta.

Dalam undang-undang tidak didefinisikan mengenai pengertian hak moral. Hak moral sendiri diatur pada Pasal 5-7 Undang-undang Republik Indonesia Nomor 28 Tahun 2014 Tentang Hak Cipta ${ }^{9}$ Secara doktrinal,

8 Aim Abdulkarim, 2004, Kewarganegaraan, Grafindo Media Pratama, Jakarta, hlm. 94.

9 Pasal 5 Undang-undang Republik Indonesia Nomor 28 Tahun 2014 Tentang Hak Cipta (1) Hak moral sebagaimana dimaksud dalam Pasal 4 merupakan hak yang melekat secara abadi padadiriPenciptauntuk: a.tetapmencantumkan atau tidak mencantumkan namanya pada salinan sehubungan dengan pemakaian Ciptaannya untuk umum; b. menggunakan nama aliasnya atau samarannya; c. mengubah Ciptaannya sesuai dengan kepatutan dalam masyarakat; d. mengubah judul dan anak judul Ciptaan; dan e. mempertahankan haknya dalam hal terjadi distorsi Ciptaan, mutilasi Ciptaan, modifikasi Ciptaan, atau hal yang bersifat merugikan kehormatan diri atau reputasinya. (2) Hak moral sebagaimana dimaksud pada ayat (1) tidak dapat dialihkan selama Pencipta masih hidup, tetapi pelaksanaan hak tersebut dapat dialihkan dengan wasiat atau sebab lain sesuai dengan ketentuan peraturan perundang- 
hak moral terdiri dari hak-hak yang sebagai berikut:

a. Hak pengakuan sebagai pencipta (authorship right atau paternity right) apabila karya cipta yang dihasilkan oleh pencipta tersebut diperbanyak, diumumkan atau dipamerkan dihadapan publik. Karya tersebut harus mencantumkan nama penciptanya.

b. Hak keutuhan karya (the right to protect the integrity of the work) yakni hak untuk tidak melakukan perubahan terhadap ciptaan tanpa persetujuan dari pencipta, atau ahli warisnya. Perubahan tersebut misalnya dilakukan dengan pemutarbalikan, perusakan, pemotongan, dan penggantian yang berhubungan dengan karya cipta.

c. Hakpenciptauntukmengandakan perubahan pada ciptaan sesuai dengan tuntutan perkembangan zaman serta kepatutan dalam masyarakat. ${ }^{10}$

Perlindungan hak moral foto karya citizen journalist di Instagram dapat dilihat dari pencantuman atau tidak mencantumkan nama atau menggunakan nama samaran citizen

undangan setelah Pencipta meninggal dunia. (3) Dalam hal terjadi pengalihan pelaksanaan hak moral sebagaimana dimaksud pada ayat (2), penerima dapat melepaskan atau menolak pelaksanaan haknya dengan syarat pelepasan atau penolakan pelaksanaan hak tersebut dinyatakan secara tertulis.

10 Abdul Kadir Muhammad, 2001, Kajian Hukum Ekonomi Hak Kekayaan Intelektual, PT. Citra Aditya Bakti, Bandung, hlm. 21. journalist dalam karya cipta foto tersebut sepanjang digunakan untuk kepentingan umum. Apabila digunakan untuk kepentingan komersial, maka sistem elektronik wajib mencantumkan nama citizen journalist pencipta karya foto tersebut. Citizen journalist dalam konsep normative hak cipta disebut sebagai pencipta, sedangkan Instagram, khususnya pemilik akun Instagram yang bergerak di bidang pers merupakan pemegang hak cipta.

Sebagai sebuah karya yang disajikan melalui sistem elektronik, maka pencipta dapat melindungi hak cipta fotonya melalui informasi elektronik hak cipta. informasi elektronik hak cipta meliputi informasi tentang suatu ciptaan, yang muncul dan melekat secara elektronik dalam hubungan dengan kegiatan pengumuman ciptaan; pencipta sebagai pemegang hak cipta; nama pencipta, aliasnya atau nama samarannya; masa dan kondisi penggunaan ciptaan; nomor; dan kode informasi. Dengan demikian, hasil foto tersebut tidak dapat digunakan oleh media online lain tanpa seizin atau tanpa mencantumkan penciptanya.

Pada media online, pemilik akun media online melindungi hak moral pencipta dengan mencantumkan sumber (pemilik) foto dan juga menuliskan nama atau logo akun media online. Hal tersebut dilakukan untuk mencegah media lain menggunakan foto tersebut sebagai ilustrasi berita yang dibuatnya tanpa mencantumkan 
sumber foto yang sesungguhnya, melakukan mutilasi ciptaan, distorsi ciptaan, modifikasi ciptaan yang merugikan pencipta dan pemegang hak cipta.

Hak cipta sebagai salah satu hak kekayaan intelektual memiliki sifat-sifat sebagaimana hak kekayaan intelektual pada umumnya. Pada intinya hak kekayaan intelektual adalah hak untuk menikmati secara ekonomis terhadap suatu kreativitas intelektual. dari objek yang diatur. Karya-karya tersebut timbul atau lahir karena kemampuan intelektual manusia. ${ }^{11}$ Kemampuan intelektual tersebut dihasilkan dari pikiran, kemampuan, inspirasi, imajinasi, kecekatan, keterampilan, atau keahlian yang diekspresikan dan diwujudkan dalam sebuah karya nyata. Hak kekayaan intelektual dan hak asasi manusia memiliki penekanan yang sama yakni pada property rights dan individual rights. ${ }^{12}$

Hak kekayaaan intelektual memang merupakan istilah umum dari hak eksklusif yang timbul karena hasil kreativitas dan kegiatan intelektual manusia. Dalam kegiatan bisnis, eksistensi hak cipta sebagai hak kekayaan intelektual ini diakui. Hasil

11 Direktorat Jendral Hak Kekayaan Intelektual, 2006, Buku Panduan Hak Kekayaan Intelektual, Direktorat Jendral Hak Kekayaan Intelektual, Jakarta, hlm. 2

12 Ni Ketut Supasti Dharmawan, 2014, Relevansi Hak Kekayaan Intelektual dengan Hak Asasi Manusia Generasi Kedua, Jurnal Dinamika Hukum Vol. 14 No. 3 September 2014, Universitas Jenderal Soedirman, Purwokerto, hlm. 526 . ciptaan termasuk ke dalam hak yang tidak berwujud (intangible) dari benda yang juga tidak berwujud namun memiliki nilai ekonomis. ${ }^{13}$ Pengaturan mengenai hak ekonomi secara umum diatur dalam Pasal 8-11 Undangundang Republik Indonesia Nomor 28 Tahun 2014 Tentang Hak Cipta. Dalam Pasal 15 ayat (1) huruf a UndangUndang Hak Cipta disebutkan bahwa perlindungan hak cipta atas ciptaan berupa karya fotografi berlaku selama 50 (lima puluh) tahun sejak pertama kali dilakukan pengumuman. Terkait dengan karya foto citizen journalist, maka jenis hak ekonomi karya cipta tersebut adalah hak perbanyakan (penggandaan), yaitu dengan penambahan jumlah ciptaan dengan pembuatan yang hampir sama, sama, atau menyerupai ciptaan tersebut, baik dengan menggunakan bahanbahan yang sama maupun bahanbahan yang tidak sama, termasuk pengalihwujudkan ciptaan. ${ }^{14}$

Pada dasarnya, hak ekonomi terkait dengan penggunaan secara komersial. Penggandaan foto pada media sosial tentu saja sangat mudah dilakukan. Netizen hanya perlu membagikan (share) pada akun yang dimilikinya, menautkan dan dapat pula menyimpan foto yang dimilikinya.

13 Direktorat Jenderal Hak Kekayaan Intelektual Departemen Hukum dan Hak Asasi Manusia Republik Indonesia, 2007, Penegakan Hukum di Bidang Hak Kekayaan Intelektual, Direktorat Jenderal Hak Kekayaan Intelektual Departemen Hukum dan Hak Asasi Manusia Republik Indonesia, Jakarta, hlm. 1.

14 Abdul Kadir Muhammad, Op.Cit., hlm. 19. 
Beberapa jenis foto sering diambil dari Instagram dan digunakan untuk kegiatan komersil, seperti foto kue yang diposting oleh seseorang, kemudian diambil oleh orang lain dan diakui sebagai portofolio kuenya. Karya fotografi memiliki nilai ekonomi dimana banyak peristiwa, hal, atau benda yang dapat diabadikan melalui karya tersebut.

Hak ekonomi tidak diberikan apabila karya foto tersebut memuat protret (dengan objek manusia) tanpa seizin dari orang yang ada dalam potret atau ahli warisnya. Orang dalam objek foto dapat menuntut orang yang mempublikasikan foto tersebut tanpa seizinnya. Hal ini merupakan amanat darikebebasanpers, dimanapenyebaran informasi dapat dilakukan sepanjang tidak bertentangan dengan privasi. Danrivanto Budhijanto berpandangan bahwa kebebasan memperoleh informasi adalah hak asasi yang harus berakhir karena adanya perlindungan terhadap hak-hak pribadi. Selanjutnya beliau mencontohkan bahwa negara seliberal Amerika Serikat pun tetap menghargai dan menjunjung tinggi kebebasan memperoleh informasi, namun tidak diperkenankan melanggar hak-hak pribadi dari seseorang. ${ }^{15}$

Di Jepang, masalah perlindungan atas privasi ini telah menjadi perhatian pihak yang berwenang dengan membuat aturan yang memuat perlindungan atas pelanggaran dan

15 Danrivanto Budhijanto, 2010, Hukum Telekomunikasi, Penyiaran \& Teknologi Informasi Regulasi dan Konvergensi, Refika Aditama, Bandung, hlm. 3. penyahgunaan informasi pribadi dari satu sumber ke dalam suatu daftar dan menjualnya kepada pihak lain. ${ }^{16}$ Merujuk pada ketentuan demikian, maka seorang citizen journalist tidak boleh mengunggah foto karyanya yang dapat menyerang privasi seseorang. Kebebasan tidak dapat diartikan sebagai berbuat sekehendak tanpa batas atau tanpa menjaga kebebasan orang lain. Kebebasan mengandung makna yang mendalam yakni sebuah pengakuan dan penghormatan terhadap dan kewajiban setiap manusia. ${ }^{17}$

\subsection{Upaya-upaya yang Dapat Dilakukan Seorang Citizen Journalist untuk Melindungi Karya Cipta Fotonya yang diunggah di Instagram}

Berbicara mengenai upayaupaya yang dapat dilakukan seorang citizen journalist untuk melindungi karya cipta fotonya yang diunggah di Instagram, maka akan berhadapan dengan dua tiga hal yakni upaya preventif, upaya represif dan upaya pre-emtif. Dalam aplikasi Instagram, telah dirancang teknologi sedemikian rupa yang menyebabkan pengguna tidak dapat menyimpan foto. Mereka hanya dapat menautkan dengan para pengguna Instagram yang lain. Walaupun tidak secara langsung dapat menyimpan foto karya citizen

16 Asril Sitompul, 2004, Hukum Internet (Pengenalan Mengenai Masalah Hukum di Cyberspace), Citra Aditya Bakti, Bandung, hlm. 26-27.

17 Samsul Wahidin, 2006, Hukum Pers, Pustaka Pelajar, Yogjakarta, hlm. 24. 
journalist, namun dengan kecanggihan teknologi, netizen dapat melakukan foto layar(screen shoot) dan memotong bagian-bagian yang perlu dihilangkan (crop) untuk mendapatkan hasil yang diinginkan. Netizen dapat mengunggah ulang foto tersebut dan mungkin sekali untuk menjual hasil karyanya kepada orang lain. Perbuatan tersebut tentu tidak adil bagi citizen journalist yang memang memberikan hasil fotonya tanpa berbayar kepada akun media di Instagram. John Jay menyatakan justice is indiscriminately due to all, without regard to numbers, wealth, or rank. ${ }^{18}$ Keadilan adalah perbuatan nondiskriminasi kepada seseorang, baik mengenai jumlah, kesejahteraan atau peringkat. Oleh sebab itu, diperlukan upaya untuk melindungi hak cipta atas karya fotografi yang diunggah di Instagram.

Upaya preventif dilakukan dengan mengedukasi netizen dan akun pers di Instagram untuk memenuhi hak moral dan hak ekonomi atas hasil karya fotografi yang dihasilkan oleh citizen journalist. Pemenuhan hak moral dapat dilakukan mencantumkan nama citizen journalist yang mengirimkan hasil karyanya ke akun pers di Instagram. Upaya lain yang dapat dilakukan adalah dengan melindungi hak keutuhan karya foto yang dihasilkan citizen journalist. Artinya,

18 Achmad Ali, 2009, Menguak Teori Hukum (Legal Theory dan Teori Peradilan (Judicialprudence) Termasuk Intepretasi Undang-undang (Legisprudence), Kencana, Jakarta, hlm. 221. netizen tidak diperbolehkan untuk mengubah (melakukan editing, crop dan sebagainya) terhadap hasil karya foto yang telah diunggah tersebut.

Sehubungan dengan pergeseran paradigma jurnalisme sebagaimana yang telah diuraikan sebelumnya, pada dasarnya, citizen journalist tidak memperjualbelikanhasilkaryafotonya. Mereka hanya ingin berbagi informasi kepada masyarakat, namun dalam pemenuhan hak ekonominya, seorang citizen journalist dapat memperoleh keuntungan ekonomi dari akun pers di aplikasi Instagram. Biasanya akunakun tersebut akan memberikan souvenir atau pembayaran berupa uang kepada citizen journalist yang karya fotonya dimuat dalam akun media tersebut. Seorang Citizen journalist hendaknya mempertimbangkan pula keputusannyaapabilaakanmemberikan hasil karyanya untuk dipublikasikan. Apabila memang peristiwa yang difoto berpotensi memberikan keuntungan ekonomi, maka citizen journalist dapat meminta hak ekonomi kepada akun pers di Instagram yang akan mempublikasikan karya tersebut atau pihak lain yang tertarik akan karya fotografinya.

Upaya represifdilakukan melalui penegakan hukum sebagaimana yang diatur dalam Undang-undang Republik Indonesia Nomor 28 Tahun 2014. Penyelesaian sengketa hak cipta dapat dilakukan melalui pengadilan (pengadilan niaga) dan melalui alternatif penyelesaian sengketa 
berdasarkan Bab XIV Undang-undang Republik Indonesia Nomor 28 Tahun 2014. Tuntutan pidana dilakukan berdasarkan Pasal 113 ayat (3) bagi setiap orang yang dengan tanpa hak/ atau tanpa izin Pencipta atau Pemegang Hak Cipta melakukan pelanggaran hak ekonomi Pencipta sebagaimana dimaksud dalam Pasal9 ayat(1) hurufa, huruf $b$, hurufe, dan/ atau huruf g untuk penggunaan secara komersial dipidana dengan pidana penjara paling lama 4 (empat) tahun dan/ atau pidana denda paling banyak Rp.1.000.000.000,(satu milyar rupiah). Gugatan perdata tidak menghilang hak bagi pencipta karya foto untuk mengajukan tuntutan pidana. Upaya pre-emtif yang dapat dilakukan adalah dengan membina akun-akun pers yang belum memenuhi hak moral dan/ atau ekonomi kepada citizen journalist melalui Dewan Pers Nasional.

\section{KESIMPULAN}

1. Perlindungan hak moral foto citizen journalist di Instagram dilakukan dengan penyebutan nama pencipta (citizen journalist) dan pemegang hak cipta (akun pers pada Instagram). Penggandaan hanya dilakukan untuk kepentingan umum, bukan untuk kepentingan komersial yang dapat merugikan pencipta. Berkaitan dengan perlindungan hak ekonomi, dalam implementasinya, pada umumnya pihak pemilik akun pers telah memberikan reward/ insentif sebagai penghargaan terhadap hak ekonomi yang dimiliki oleh seorang citizen journalist.

2. Upaya-upaya yang dapat dilakukan seorang citizen journalist untuk melindungi karya cipta fotonya yang diunggah di Instagram adalah upaya preventif melalui edukasi mengenai perlindungan hak cipta, upaya respresif melalui penegakan hukum baik melalui perdata dan pidana serta upaya pre-emtif melalui pembinaan oleh Dewan Pers Nasional.

\section{DAFTAR PUSTAKA}

\section{BUKU}

Abdul Kadir Muhammad, 2001, Kajian Hukum Ekonomi Hak Kekayaan Intelektual, PT. Citra Aditya Bakti, Bandung.

Achmad Ali, 2009, Menguak Teori

Hukum (Legal Theory dan Teori

Peradilan (Judicialprudence)

Termasuk Intepretasi Undangundang (Legisprudence), Kencana, Jakarta..

Aim Abdulkarim, 2004, Kewarganegaraan, Grafindo Media Pratama, Jakarta.

Asril Sitompul, 2004, Hukum Internet (Pengenalan Mengenai Masalah Hukum di Cyberspace), Citra Aditya Bakti, Bandung.

Danrivanto Budhijanto, 2010, Hukum Telekomunikasi, Penyiaran \& 
Teknologi Informasi Regulasi dan Konvergensi, Refika Aditama, Bandung.

Direktorat Jenderal Hak Kekayaan Intelektual Departemen Hukum dan Hak Asasi Manusia Republik Indonesia, 2007, Penegakan Hukum di Bidang Hak Kekayaan Intelektual, Direktorat Jenderal Hak Kekayaan Intelektual Departemen Hukum dan Hak Asasi Manusia Republik Indonesia, Jakarta.

Direktorat Jendral Hak Kekayaan Intelektual, 2006, Buku Panduan Hak Kekayaan Intelektual, Direktorat Jendral Hak Kekayaan Intelektual, Jakarta.

Gatot Supramono, 2010, Hak Cipta dan Aspek-Aspek Hukumnya, Rineka Cipta, Jakarta.

Samsul Wahidin, 2006, Hukum Pers, Pustaka Pelajar, Yogyakart

Supasti Dharmawan, Ni Ketut, 2011, Hak Kekayaan Intelektual dan Harmonisasi Hukum Global Rekonstruksi Pemikiran Terhadap Perlindungan Program Komputer, Badan PenerbitUniversitasDiponegoro, Semarang.

\section{PERATURAN}

\section{PERUNDANG-UNDANGAN}

Undang-undang Nomor 40 Tahun 1999 tentang Pers.

Undang-undang Republik Indonesia Nomor 28 Tahun 2014 Tentang Hak Cipta.

\section{JURNAL}

Denny Kusmawan,2014,Perlindungan Hak Cipta Atas Buku, Jurnal Perspektif Volume XIX No. 2 Tahun 2014 Edisi Mei, Surabaya.

Emma Valentina Teresha Senewe, 2015, Efektivitas Pengaturan Hukum Hak Cipta Dalam Melindungi Karya Seni

Tradisional Daerah, Jurnal LPPM Bidang EkoSosBudKum Volume 2 Nomor 2 Tahun 2015 Edisi Oktober, Manado.

Supasti Dharmawan, Ni Ketut, 2014,

Relevansi Hak Kekayaan Intelektual dengan Hak Asasi Manusia Generasi Kedua, Jurnal Dinamika Hukum Vol. 14 No. 3 September 2014, Universitas Jenderal Soedirman, Purwokerto.

Yuliana Diah Warsiki Susi Irianti, 2014, Perlindungan Hak Moral Dalam Hukum Hak Cipta, Jurnal Hukum dan Masyarakat Volume XIII, Nomor 3, Kupang. 